\title{
Grazing Systems: More Thoughts and Observations
}

\section{By Lee E. Hughes}

\section{W}

Rotation grazing does improve species composition. It just needs an area open to improvement and sound application ith the publication in January 2008 of "Rotational grazing on rangelands: reconciliation of perception and experimental evidence" by Briske et al., ${ }^{1}$ the debate about grazing systems was reopened. The paper compared rotation grazing and continuous grazing for plant production. It found little difference between the two overall for production based on the published studies it surveyed.

That paper was followed by the October 2009 Rangelands issue dedicated to the debate on rotational grazing. In that issue, Budd and Thorpe ${ }^{2}$ write on grazing systems from a manager's standpoint. They encouraged expanding the discussion to include data from federal land agencies, consultants, landowners, and others who monitor grazing systems. Budd and Thorpe endorsed evaluation of grazingsystem-monitoring data from different regions, their ecosystems, and their respective grazing systems, as well as how these systems performed in attaining their objectives in those ecosystems.

The Bureau of Land Management's Arizona Strip District has more than 600 key areas for grazing system monitoring studies (seral stage condition and species frequency) that were developed with researchers from the University of Arizona and range managers from the district and the extension service. The studies have been consistently read and the methods unchanged since 1980. The data, on evaluation, show some answers from a management standpoint.

\section{What About Species Composition or Frequency Change?}

The Briske paper cites Teague and Downhower, ${ }^{3,4}$ who demonstrated that rest periods in their grazing systems facilitated improved species composition in frequently grazed patches as opposed to continuously grazed patches. In the grazing systems on the Arizona Strip such improvement has been recorded in our trend measurement areas. Some have showed little to no change, and they are generally areas in

\section{Sidebar}

\section{Vegetation Measurement}

The three methods we used to measure vegetation were Pace Frequency, Dry Weight Rank, and Line Point Transects. The Pace Frequency Transects are done over about a 1-acre area using four 50-plot transects. The center line is marked by two steel fence posts, and two transects are conducted on each side of the center line. The plot used is $39 \mathrm{~cm} \times 39 \mathrm{~cm}$ and has a point in the frame to tally ground cover (live vegetation, litter, bare ground, and rock). The plot counts herbaceous vegetation if it is rooted within the plot boundaries. Woody vegetation is counted if it is rooted in and overhangs the plot.

Dry Weight Rank is used to get weight estimates by rank. It measures the three heaviest plants in the plot. The heaviest plant is given the rank of 7 , the second is ranked at 2 , and the third is ranked as 1 . If there is only one plant in the plot, it is given all three rankings for a total of 10. The composition data from dry weight rank is then compared with the ecological site guides in the USDA Natural Resource Conservation Service publication of the Soil Survey of the Mohave County. ${ }^{7}$ Table 6 in that publication shows the ecological sites at potential natural community (PNC) status. The species composition data gathered in the dry weight transects were compared to the PNC tables in the site guides. If the species present in the transect added up to less than $25 \%$ of the PNC, it was assigned an early seral stage, $26-50 \%$ mid-seral, $51-75 \%$ late seral, and $76 \%+$ PNC.

The Line Point Transect uses a 100-foot tape stretched between two rebar. At each foot mark, a three-quarter-inch loop is lowered, and all layers of vegetation are recorded in a vertical manner to the ground. Ground cover is noted when there is no vegetation to record at the measure point on the tape. The frequency of vegetation measured by the 200 plots indicates change when there is at least $10 \%$ change in a species occurrence either up or down. 


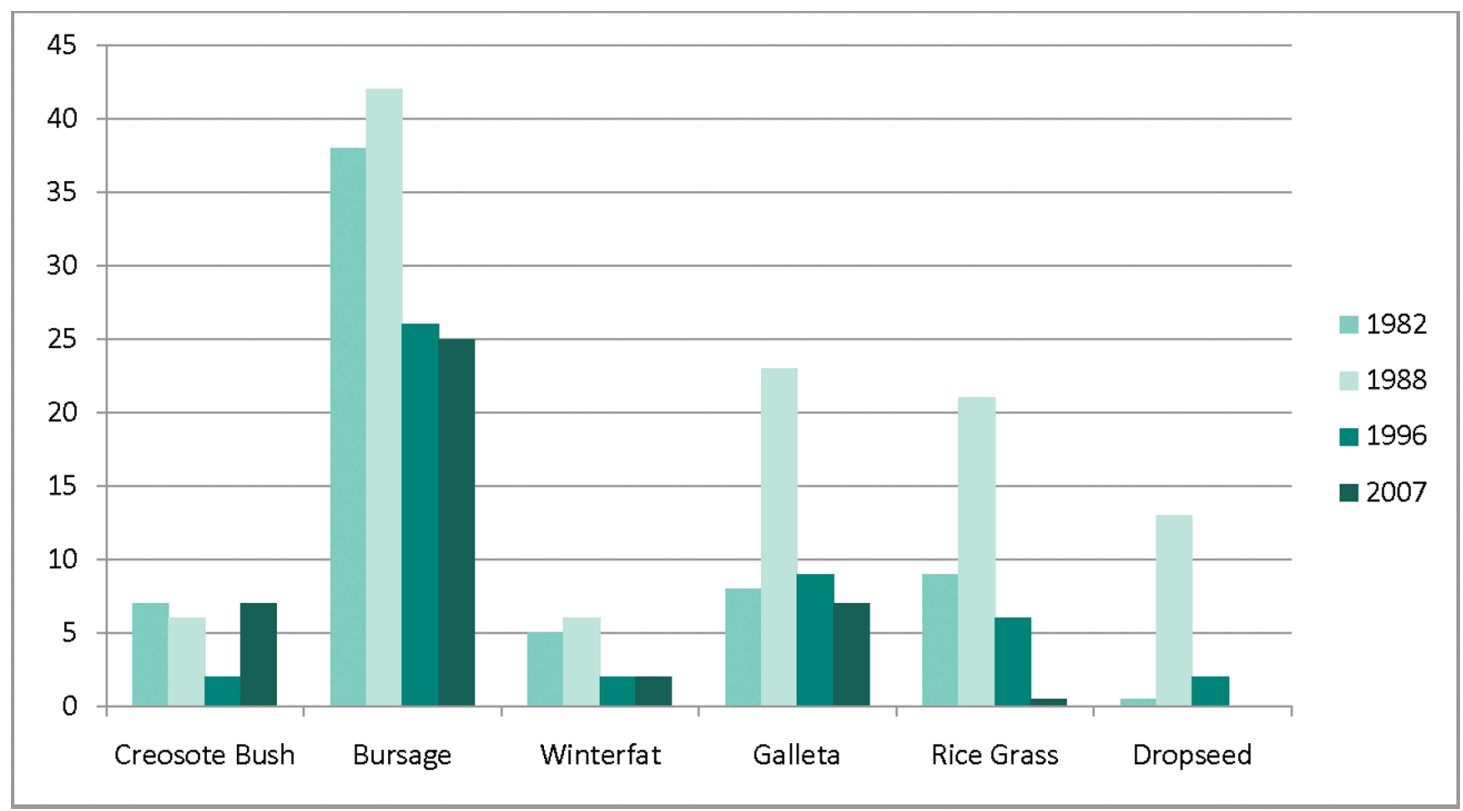

Figure 1. Plant species frequency trend at pasture, one key area in the Beaver Dam Slope Allotment. This key area is in a Limy Upland Deep 6-9-inch precipitation zone ecological site.

late seral and potential natural community stages, which leave little room for species composition change.

\section{An Example of Little to No Change}

In 1968 a three-pasture deferred rotation grazing system was implemented on a Mojave Desert allotment—the Beaver Dam Slope Allotment. The allotment was grazed from November to June. In my 1982 Rangelands paper "A Grazing. System in the Mohave Desert," ${ }^{\prime 5}$ the trend data showed loss of some species and gain of others from 1970 to 1980, but little change occurred in the vegetation from the grazing system. From this experience, no other Mohave Desert allotments were put on grazing systems after 1980. The desert allotments remained on fall-to-spring season-long use.

Fifteen years later in 1995 (though actually it went into effect in 1999 because of legal appeals), all cattle were required to be moved off most Mohave Desert allotments on 15 March instead of 30 May, to satisfy critical habitat requirement for the desert tortoise, a listed threatened species. The 1995 decision held that all desert tortoise critical

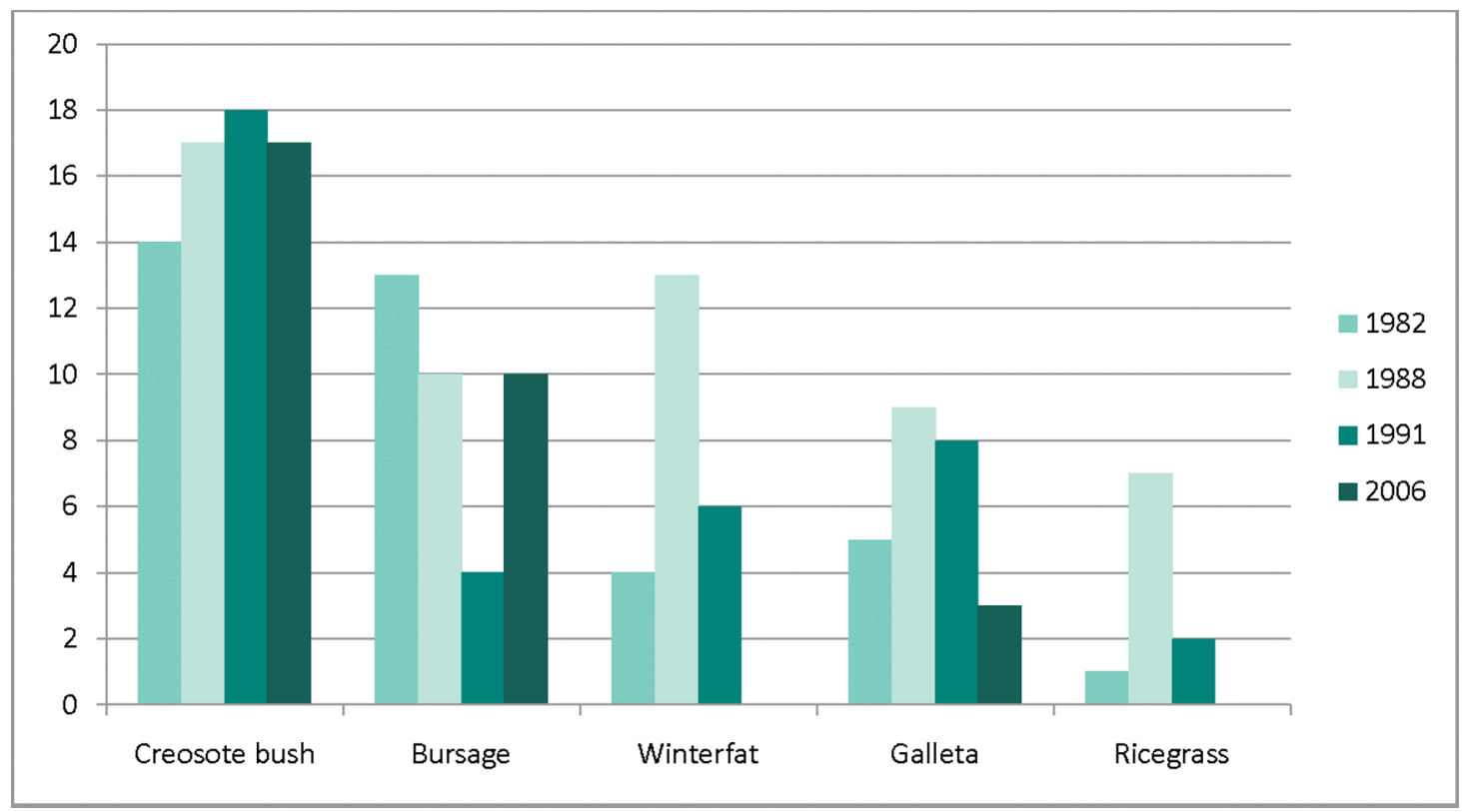

Figure 2. Mormon Well Allotment Frequency Trend showing the number of plants per species. This allotment has been under season-long continuous grazing since regulated grazing began on public lands. This key area is in a Limy Upland Deep 6-9 inch precipitation zone ecological site. Table 1 shows species frequency. 
Table 1. Ecological site

\begin{tabular}{|c|c|c|c|c|c|}
\hline $\begin{array}{l}\text { Ecological seral } \\
\text { stage }\end{array}$ & $\begin{array}{l}\text { Current composition } \\
2007 \text { Beaver Dam } \\
\text { weight data }\end{array}$ & $\begin{array}{c}\text { Current composi- } \\
\text { tion } 2006 \text { Mormon } \\
\text { Well }\end{array}$ & $\begin{array}{l}\text { Limy Upland } \\
\text { Deep 6-9-inch } \\
\text { site guide }\end{array}$ & $\begin{array}{c}\text { Total score: } 56, \\
\text { late seral stage, } \\
\text { Beaver Dam }\end{array}$ & $\begin{array}{c}\text { Total score: } 64 \text {, } \\
\text { late seral stage, } \\
\text { Mormon Well }\end{array}$ \\
\hline Creosote bush & 14 & 40 & 30 & 14 & 30 \\
\hline Bursage & 50 & 48 & 30 & 30 & 30 \\
\hline cactus & 7 & 0 & 0 & 0 & 0 \\
\hline Turpentine bush & 0 & 0 & 2 & 1 & 0 \\
\hline $\begin{array}{l}\text { Ratany (Krameria } \\
\text { grayi) }\end{array}$ & 5 & 2 & 3 & 3 & 2 \\
\hline Big galleta grass & 16 & 7 & 2 & 2 & 2 \\
\hline Indian rice grass & 2 & 0 & 2 & 2 & 0 \\
\hline $\begin{array}{l}\text { Tea (Ephedra } \\
\text { nevadensis) }\end{array}$ & 2 & 0 & 3 & 2 & 0 \\
\hline
\end{tabular}

Based on Natural Resources Conservation Service Soil Survey of Shivwits Area, Arizona, Part of Mohave County. ${ }^{7}$ Data are weight based to determine seral stage because seral stage is based on composition as opposed to frequency data.

habitat would have grazing from October to 15 March, rather than to 30 May. So with a very short grazing period both allotments receive only winter use. The Beaver Dam Allotment still rotates the cattle, but it occurs with one or two pastures being grazed each winter rather than all three; the other one or two are rested from grazing.
Figure 1 shows change through the years in the Beaver Dam Slope Allotment since 1980. The trend of the vegetation is related to the wetter weather in the 1980s and 1990s and the drier years in the 2000s. Big galleta grass (Pleuraphis rigida) and Indian rice grass (Achnatherum hymenoides) showed increases in the 1980s and early 1990s and then in

\section{Table 2. Grazing systems schematics of Beaver Dam and Clayhole allotments}

\begin{tabular}{|c|c|c|c|c|}
\hline \multicolumn{5}{|c|}{ Beaver Dam Slope Allotment Grazing System } \\
\hline 1974-1995* & November 1 & March 1 & April 15 & May 30 \\
\hline Pasture 1 & Graze & \multicolumn{3}{|l|}{ Rest } \\
\hline Pasture 2 & Rest & Graze & & \\
\hline Pasture 3 & \multicolumn{2}{|l|}{ Rest } & Graze & \\
\hline After 1995† & \multicolumn{3}{|l|}{ November 1} & March 15 \\
\hline Pasture 1 & \multicolumn{4}{|l|}{ Graze } \\
\hline Pasture $2 \& 3$ & \multicolumn{4}{|l|}{ Rest } \\
\hline \multicolumn{5}{|c|}{ Clayhole Grazing System to 1993} \\
\hline North Unit‡ & January 1 & \multicolumn{3}{|l|}{ March 1} \\
\hline Pasture 1 & Rest & \multicolumn{3}{|l|}{ Graze } \\
\hline Pasture 2 & \multicolumn{4}{|l|}{ Graze } \\
\hline Pasture 3 & \multicolumn{4}{|l|}{ Rest } \\
\hline South Unit§ & January 1 & March 1 & & December 31 \\
\hline Pasture 1 & Rest & \multicolumn{3}{|l|}{ Graze } \\
\hline Pasture 2 & \multicolumn{4}{|l|}{ Graze } \\
\hline Pasture 3 & \multicolumn{4}{|l|}{ Graze } \\
\hline Pasture 4 & \multicolumn{4}{|l|}{ Graze } \\
\hline Pasture 5 & \multicolumn{4}{|l|}{ Graze } \\
\hline Pasture 6 & \multicolumn{4}{|l|}{ Rest 1 year } \\
\hline \multicolumn{5}{|c|}{$\begin{array}{l}\text { * Repeat cycle every three years. Each pasture receiving rest and graze as shown above over a three-year cycle. } \\
\text { †Pasture } 1 \text { is grazed one year and rested the next. Pastures } 2 \text { and } 3 \text { are grazed alternate year of Pasture } 1 \text { and rested alternate } \\
\text { year of Pasture } 1 \text {. } \\
\text { †Each pasture receives each rest-graze treatment once every three years. }\end{array}$} \\
\hline
\end{tabular}




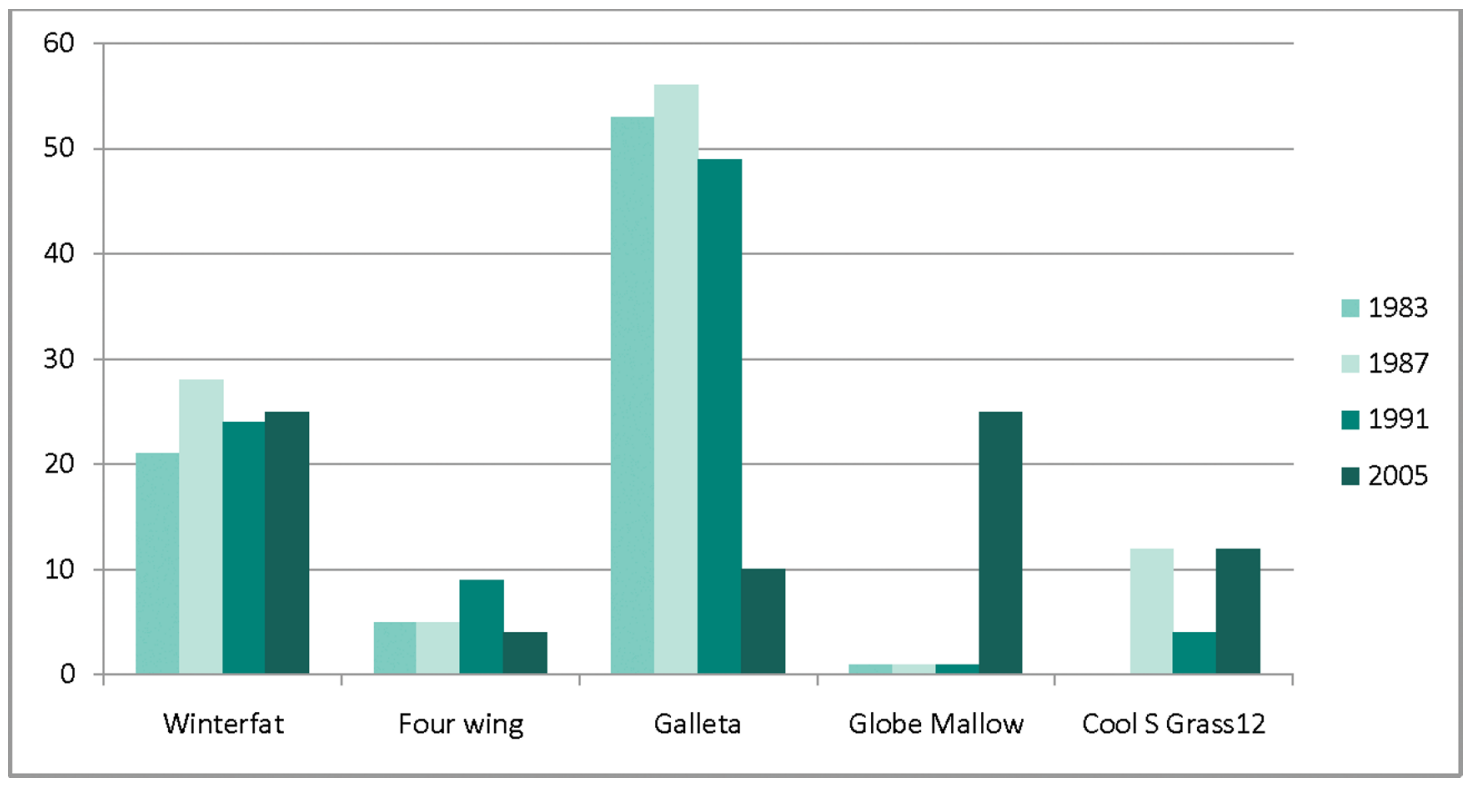

Figure 3. Inside the South Exclosure built in 1950. Four line point transects data are shown in total. This shows the number of plants of the listed plants occurring along the four 100-foot tapes where vegetation at each foot mark that was encountered in the three-fourths-inch loop placed at each foot mark. No grazing since 1950.

the 2000s showed decreases. The shrubs and forbs showed similar increases and decreases.

Next to this allotment is the Mormon Well Allotment on the same ecological site. The frequency trend as shown in Figures 1 and 2 is similar, though the big galleta grass and Indian rice grass did not show similar increases, as in Beaver Dam Slope Allotment, in the 1980s and 1990s. This could be the result of the rest periods in the Beaver Dam Slope Allotment, allowing an increase of galleta and Indian rice grass frequency; however, the drought in the 2000s lowered the frequency in both allotments to similar levels even with rest and light grazing utilization levels.

Utilization in the subject key area in Mormon Well on galleta, winterfat (Krascheninnikovia lanata), Indian rice grass, and tea (Ephedra nevadensis) ranged from 2\% to 54\% from 1982 to 2010. Utilization on the same species in the Beaver Dam Slope key area ranged from $2 \%$ to $44 \%$ from 1982 to 2010.

Ecological Site Guides became available from the Natural Resource Conservation Service in the late 1990s and showed

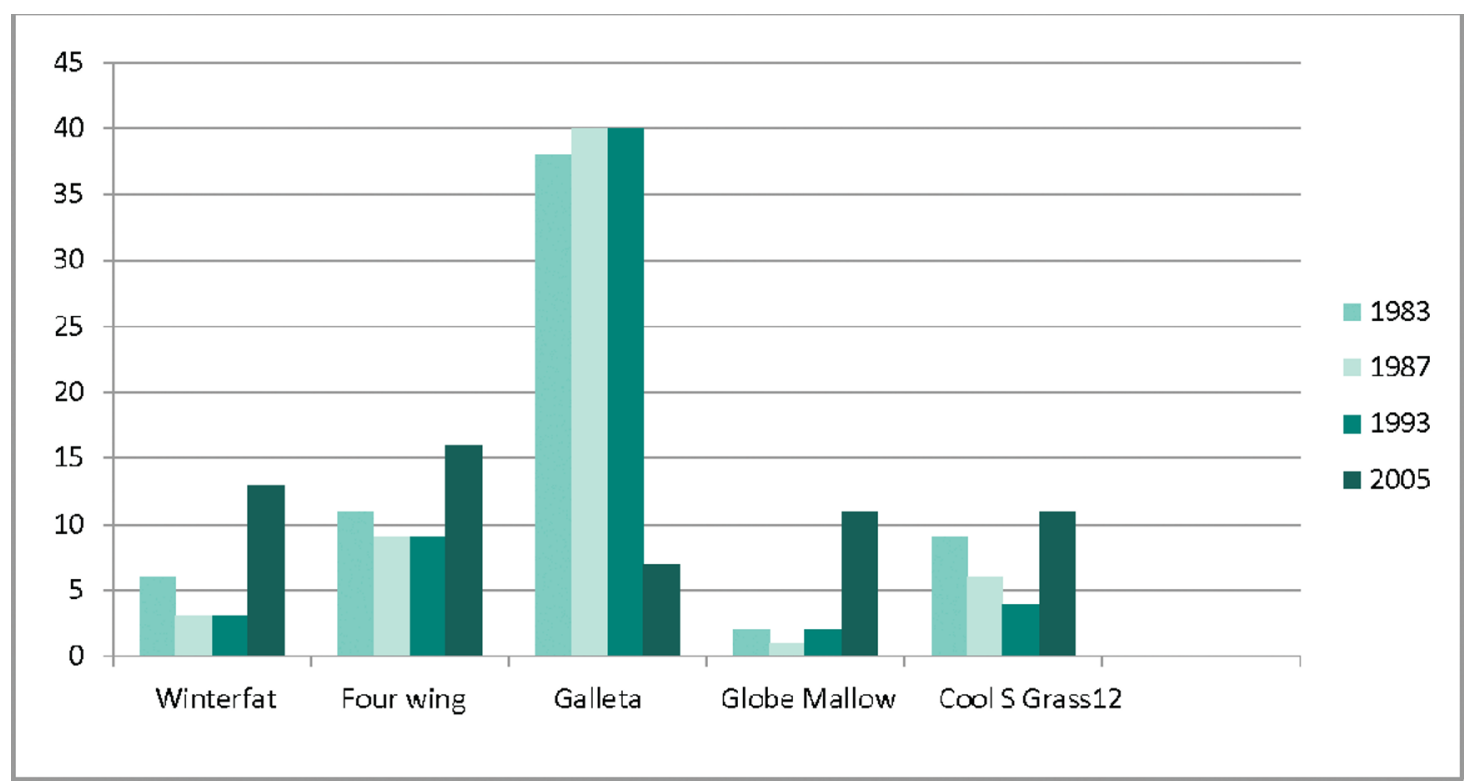

Figure 4. Outside the exclosure under rest rotation grazing to 1993. After 1993 on best pasture rotation. Pace frequency plant species data. Note change in winterfat and four wing saltbush in 2005. 


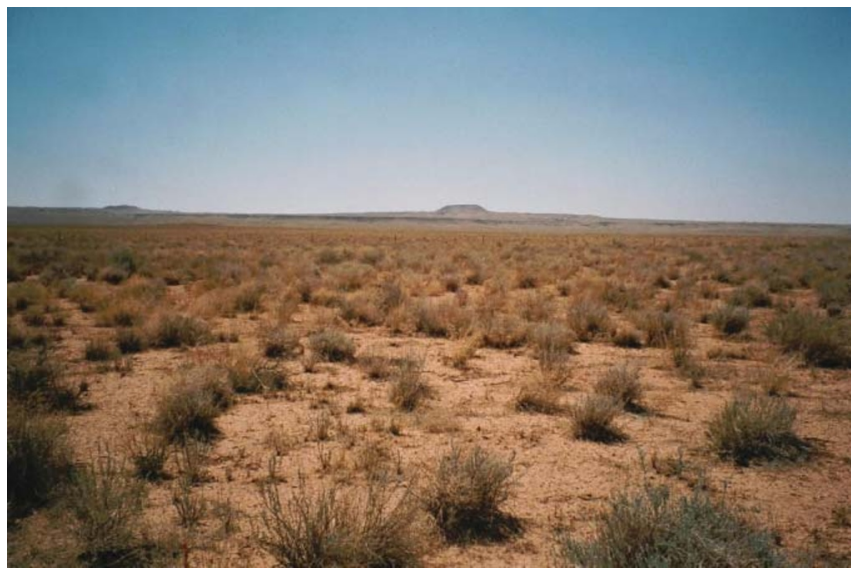

Figure 5. Outside the exclosure in the Clayhole Allotment under continuous grazing to 1968. After 1968, under rest rotation grazing. Four line-point transects. Little browse and no cool season grasses.

that the ecosystem in the Beaver Dam Slope and Mormon Well allotments were in the late seral stage (Table 1). The grazing system and the continuous use from November to June did little to alter the late seral stage.

Our conclusion from these systematic studies and observations is that there was little to no difference between the two allotments, and it appears the grazing system did not allow any permanent change or increase in the forage species over the fall-to-spring season-long grazing. Weather, as opposed to the grazing system, was the major influence.

\section{A Grazing System Doing What It Is Supposed to Do}

The Clayhole Allotment had a rest rotation grazing system implemented in 1968. The system had six pastures in the south unit and three pastures in the north unit. The graze cycle in the south unit, on any one year, had grazing in a six-year cycle. Cattle would graze four pastures for four years, and one pasture was rested each for a year and a half. One pasture was grazed for half a year. The north unit, in any one year, had one pasture rested a year and a half, one was grazed half a year, and one was grazed for a year (Table 2). After 1993, when heavy utilization problems manifested themselves in the allotment, especially around the South Exclosure in the Little Clayhole pasture, the system was changed to the best pasture system. In this system, cattle were moved on $40 \%$ utilization levels and taken to a pasture

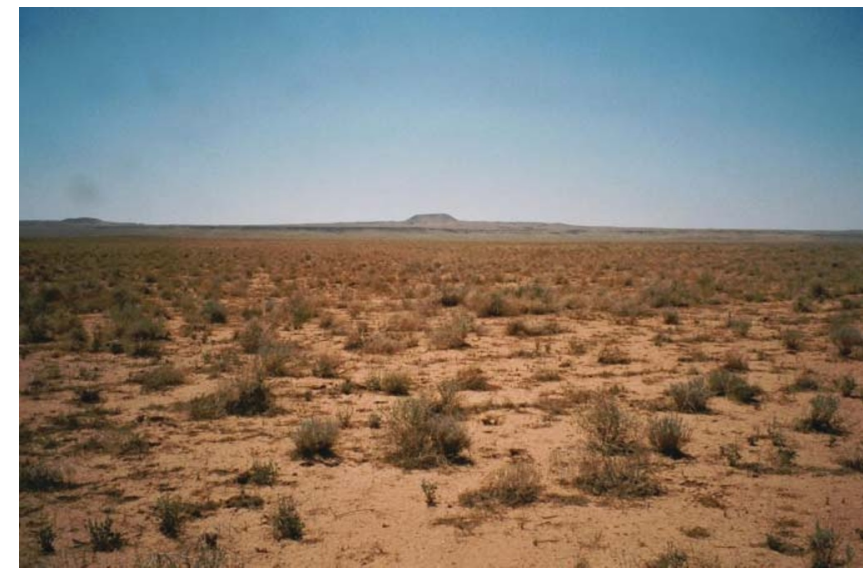

Figure 6. Outside the exclosure under rest rotation grazing to 1993. After 1993 on best pasture rotation. Pace frequency data, 200 plots each in each transect.

that looked, and studies showed, to be in best forage condition. The South Exclosure and the pasture it occurs in was the catalyst for change in management over the whole allotment. The use period in each pasture according to actual use records show one- to three-month use periods as opposed to one to four years (Clayhole Studies File 2010).

The problems of heavy utilization showed its impacts around the South Exclosure. Winterfat and fourwing salt bush (Atriplex canescens) showed a significantly higher frequency in the exclosure, which had not had grazing since 1950. The difference was evident visually and in the data (Figs. 3 and 4). In 1993, after several readings, a difference persisted through the 1980s and into the 1990s in the winterfat and fourwing between outside and inside the exclosure. ${ }^{6}$ It was felt by all participants that we could match the quantity of browse outside the exclosure, under a grazing system with lower utilization, to that under almost 50 years of rest.

\section{Some Old Transects}

Four line point transects done in and outside the exclosure in 1952, 1953, and 1991 found more galleta grass, winterfat, and fourwing in the exclosure than under grazing. No cool season grasses were found in the transects in the exclosure or outside under grazing. The cool season grass was there but had very low occurrence.

Table 3. Precipitation tables for Clayhole and Beaver Dam allotments

\begin{tabular}{|c|c|c|c|c|}
\hline & \multicolumn{2}{|c|}{ Clayhole Allotment } & \multicolumn{2}{|c|}{ Beaver Dam Slope Allotment } \\
\hline & $\begin{array}{l}\text { Precipitation range } \\
\text { (inches) }\end{array}$ & $\begin{array}{l}\text { Average precipitation } \\
\text { (inches) }\end{array}$ & $\begin{array}{l}\text { Precipitation range } \\
\text { (inches) }\end{array}$ & $\begin{array}{c}\text { Average precipitation } \\
\text { (inches) }\end{array}$ \\
\hline $1980-1989$ & $5.54-13.66$ & 9.5 & $5.54-11.51$ & 7.9 \\
\hline 1990-1999 & $4.2-15$ & 10.7 & $3.63-12.68$ & 7.9 \\
\hline $2000-2009$ & $3.63-9$ & 6.69 & $2.07-11.89$ & 6.17 \\
\hline
\end{tabular}




\section{Results 12 Years After Best Pasture Rotation Started}

In an evaluation in 2005, after being on the best pasture system for 12 years, the browse had increased in frequency under best pasture rotation grazing to the same levels as that in the exclosure-28\% under grazing and 30\% in the exclosure (Figs. 3 and 4). Formerly the best pasture was 30\% under rest from grazing and $14 \%$ under grazing. This increase occurred during the drought years of 1998-2004 (Figs. 5 and 6).

Galleta grass decreased in both the exclosure under rest from grazing and under grazing, at the same magnitude (Figs. 3 and 4). This appears to be caused by the drought from 1998 to 2004. Cool season grasses also showed up in the 1980s in the frequency transects both inside and outside the exclosure. The improvement in the browse plants can be attributed to the two grazing systems and rest from grazing, but especially to the best pasture grazing system with its lower utilization and shorter use periods. The improvement to the cool season grasses from 1983, both inside and outside the exclosure, appears weather related (Table 3).

\section{Are They Worth It?}

Grazing systems are worth it if used where needed. They prove effective if species composition or frequency is improved to desired levels. They work best where there is room for improvement in species composition or species frequency. If a grazing area is in late seral or potential natural community stage, there is no need for a grazing system or rotation grazing. Continuous seasonal use may be working with light to moderate utilization.

Where species composition can be considered to be early or mid-seral, there is a chance to improve species composition and frequency, unless some form of land treatment (fire, chemical, or mechanical) is needed to open up the plant community. The grazing system needs to be applied with reduced utilization (40-45\% of annual growth), controlled move dates, and preferably short-use periods.

Rotation grazing systems (deferred, rest rotation, best pasture, short duration, and so on) have a place in range management. If an area needs restoration, and livestock are to be grazed, then a rotation system can improve an area as it did in the area around the South Exclosure in the Clayhole grazing allotment. Like any restoration effort, follow-up actions will be needed for years.

\section{References}

1. Briske, D. D., J. D. Derner, J. R. Brown, S. D. Fuhlendorf, W. R. Teague, K. M. Havstad, R. L. Gillen, A. J. Ash, AND W. D. Willms. 2008. Rotational grazing on rangelands: reconciliation of perception and experimental evidence. Rangeland Ecology E Management 61(1):3-17.

2. Budd, B., And J. Thorpe. 2009. Benefits of managed grazing: a manager's perspective. Rangelands 31(5):11-14.

3. Teague, W. R., and S. L. Dowhower. 2003. Patch dynamics under rotational and continuous grazing management in large, heterogeneous paddocks. Journal of Arid Environments 53:211229.

4. Teague, W. R., S. L. Dowhower, and J. A. Waggoner. 2004. Drought and grazing patch dynamics under different grazing management. Journal of Arid Environments 58:97-117.

5. Hughes, Lee E. 1982. A grazing system in the Mohave Desert. Rangelands 4(6):256-257.

6. Hughes, Lee E. 1996. What's in an exclosure? Rangelands 18(5):201-203.

7. United States Department of Agriculture, Natural Resources Conservation Service. 2004. Soil survey of Shivwits area, Arizona and soil survey of Mohave Countynortheastern part. Washington, DC, USA: Department of Agriculture. 448 p.

Author is Ecologist (retired), Arizona Field Strip Office, Bureau of Land Management, St. George, UT 84790-6714, USA, lee.e.hughes@gmail.com. 